\title{
SELECTIVE WASTE COLLECTION IN THE DETACHED HOUSING AREA
}

\author{
Iwona Pasiecznik', Kamil Paweł Banaszkiewicz' , Joanna Leoniewska-Gogola²
}

1 Wrocław University of Technology, Faculty of Environmental Engineering, Wybrzeże Wyspiańskiego 27, 50-370Wroclaw, Poland, e-mail: iwona.pasiecznik@pwr.edu.pl; kamil.banaszkiewicz@pwr.edu.pl

2 Graduate from the Faculty of Environmental Engineering, Wrocław University of Technology, Wybrzeże Wyspiańskiego 27, 50-370 Wroclaw, Poland

Received: 2015.05 .14

Accepted: 2015.06 .02

Published: 2015.07.01

\begin{abstract}
When it comes to waste management, the main objective of the European Union is to prevent waste production. Produced waste should be primarily recycled or other recovery should be applied. Introduction of an effective waste collection system is a basic activity that guarantees achieving European Union agenda including the minimal level of recycling and preparation for reuse. The aim of the research was the analysis of the selective waste collection in the detached housing area (before 1st July 2013). The evaluation was prepared on the basis of an opinion research conducted among the residents. One hundred respondents, living in one of the housing estates in Wrocław, took part in the survey.
\end{abstract}

Keywords: research survey, collecting waste, selecting waste, waste recovery.

\section{INTRODUCTION}

According to Polish legislation [Journal of laws 2013], municipal waste are those produced at homes (excluding end- of-life vehicles) and those which do not include hazardous waste and are similar in character or composition to those produced at homes but are made by other waste producers. When it comes to hazardous waste, only those produced at homes are considered municipal. The amounts and the participation of particular material fractions (organic and non-organic) and determine their physical and chemical properties of municipal solid waste. The composition of waste is closely connected with the prosperity of the inhabitants, the season of the year and even the place of production even taking technical equipment of the building into consideration and having business premises inside. All those factors influence the choice of the proper waste treatment [Jędrczak and Szpadt 2006].

One of the main objectives of the European Union policy is the protection of the environment. Joining the European Union meant intro- ducing their standards to national legislation. The priorities are reducing waste production and waste disposal in landfills. The waste which are unavoidable should be primarily recycled or other recovery should be applied.

The key activity which enabled achieving European standards was the introduction of the selective waste collection. According to Central Statistical Office (CSO) in 2012 almost 97 per cent of communes in Poland conducted selective waste collection [CSO 2013]. Despite the change in collection of waste, educational and informational campaigns - the mass of selectively collected waste (paper and cardboard, glass, plastic, metal, textiles, hazardous waste, WEEE, large-size and biodegradable waste) in 2011 only 10 per cent of all municipal waste was collected. Between 2007 and 2012 selective waste collection level raised from 5 to 10,5 per cent of municipal solid waste [CSO 2008, CSO 2013]. Taking into consideration data from Central Statistical Office it can be noticed that increased level of selectively collected waste was a result of the system development and new communes joining (Figure 1). 


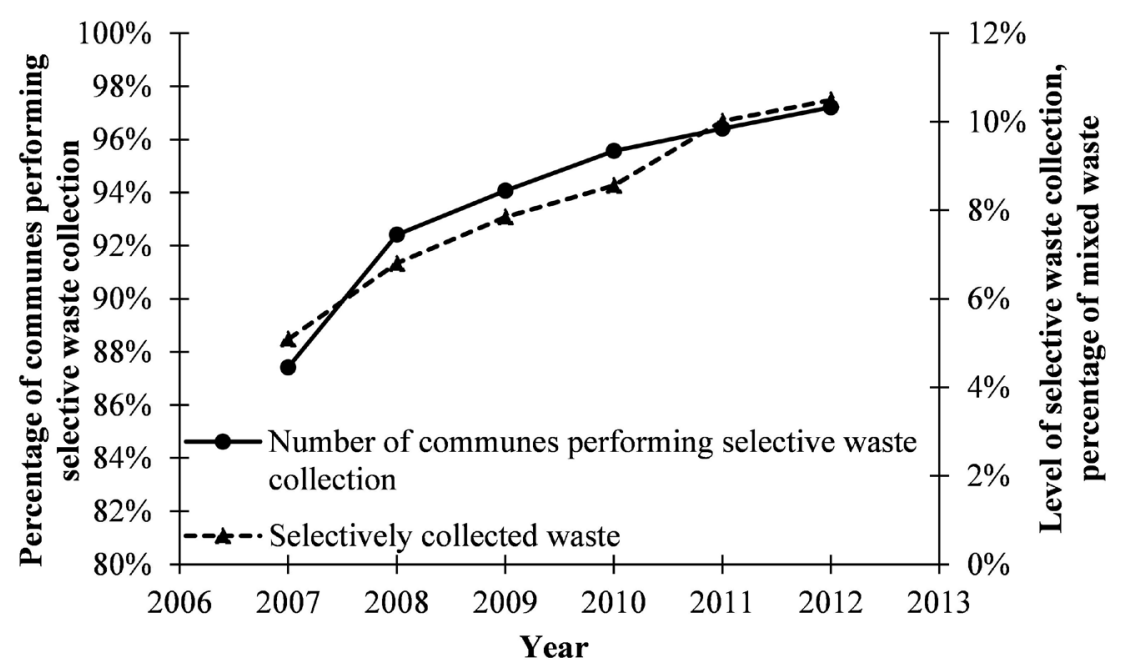

Figure 1. Introducing selective municipal waste collection between 2007 and 2012 [CSO 2008-2013]

Despite many changes and investments made in the waste management area, still the main way to deal with municipal waste is disposal in landfills. In 2012 almost 70 per cent of the collected waste was placed in landfills [CSO 2013]. This way, the materials that could be recycled (about 30 per cent of the waste mass) and the energy that could be recovered from the flammable fractions [Kwiatkowski and Faszczowy 2004] are forever lost.

Low efficiency, slow development of the existing waste management model and applying the objectives required by European Union proves that the system needs restructuring. The Act on maintaining cleanliness and order in the municipalities amended in 2011 carried full responsibility for waste and their disposal over commune councils. New system has been in effect since 1st July 2013.

The objective of the research was the evaluation of the selective municipal solid waste collection in one the suburban detached housing areas in Wrocław. 100 inhabitants of the Wojnów housing estate took part in the survey. The research was carried out in 2011 [Leoniewska 2011] before the communes took full responsibility for the waste management. The survey results have shown that the system lacks solutions which would encourage people to sort out rubbish and which would enable proper waste management.

\section{RESEARCH AREA CHARACTERISTICS}

Wojnów is the easternmost hausing estate in the Psie Pole district. It borders east with Ka- mieniec Wrocławski and Lany villages, both in commune Czernica and west with Strachocin. Strachocinska Street which is the main road of Wojnów is a part of county road number 455 [Website1]. Wojnów belongs to administrative housing estate Swojczyce-StrachociceWojnów which includes about 4500 people. The area is suburban, mostly detached houses are located there [Webside2].

In 2011 most inhabitants of Wojnów were serviced by one plant dealing with waste. According to agreement, the residents had one large container for residual waste and one additional free of charge for paper and cardboard. About 90 per cent of households decided to collect waste paper separately [Website2]. The biggest issue for the inhabitants was collecting other waste fractions separately already at home. Not till September 2011, residents had access to yellow waste bags for plastic, plastic bags, metal and composite materials (f.e. milk cartons) [Website3].

During the research the nearest drop-off point with containers for glass (divided into clear and colourful-brown and green glass) and plastic was located in the neighboring housing estate Strachocin. Available containers had the right colours and descriptions (they were serviced by a different waste treatment plant). The second nearest point was located in Swojczyce housing estate, on Myslowicka Street. The easternmost households had respectively 2,5 and 3 kilometers to points above mentioned.

Crucial factor influencing the amount of the collected waste fractions is the way of doing it. Badly organised system discourages people and introduces bad habits. Taking into consideration this area, the residents who decided not to pay 
extra for selective plastic waste collection and inserting free of charge container for paper and cardboard, had almost no possibility to sort out those waste fractions.

In 2010 in Lower Silesia over 961 thousand tones of municipal solid waste was produced (estimates based on National Waste Management Plan 2014). On the other hand, according to data from County Waste Management (Polish WSO) level of selective waste collection of paper, cardboard, metal, plastic and glass in 2010 reached 6 per cent of produced waste mass [CWMP 2012]. To Central Statistics Office [CSO 2011b] 1091 thousand tones of municipal solid waste was produced while 994 thousand tones was collected. Selective waste collection above mentioned four fractions in Lower Silesia was respectively 3,8 per cent of produced municipal waste mass and 4,1 per cent of collected waste mass [CSO 2011a]. However, the data of Central Statistics Office is rather vague and not precise for this reason called estimates [Kaca and Kaca 2012].

In case of Waste of Electrical and Electronic Equipment (WEEE), inhabitants who decided to buy new energy star appliances, could give old ones back for free at a point located in a mechanical treatment plant which collected also residual waste from the area of Wojnów. The issue which prevented people from recycling WEEE was the distance, 20 kilometers from the drop-off point. There was another WEEE collection point where residents could leave their appliances, Kielczow area 10 kilometers from the estate.

By data from Municipal Road and City Maintenance Administration (Polish ZDiUM) [Website4] published in 2011 there was no drop-off point collecting used batteries in the area of the researched housing estate. The company above mentioned prepared a general unit for the city but it was located 13 kilometers from Wojnów. So transporting batteries to far destination had no economical justification.

What is more, inhabitants of Wojnów had restricted possibilities of disposal of unused and expired medicines. None of two pharmacies located in the area collected medical waste. Information about points that gather such waste could be found on waste treatment plants' websites. But for people without Internet access e.g. elderly people, it was almost impossible to find out where to leave their medical waste.

The amount of sorted out waste confirmed that waste management system needs changes.

\section{INHABITANTS SURVEY RESEARCH}

Part of the effectiveness evaluation of waste collection system was the survey research carried out among inhabitants of the analysed estate but also direct opinions of the users which enabled to identify barriers, preventing residents from proper, ecological behaviour with the produced waste. The research was conducted in 2011 among 100 randomly chosen residents [Leoniewska 2011], constituting 2,22 per cent of Swojczyce- StrachocinWojnów area (over 8 per cent of households). Most households consisted of four people (27\%), 3 people $(23 \%)$. Only 2 percent consisted of one person.

Most respondents were over fifty years old (29\%). People aged 31 to 50 were $22 \%, 26$ to 30 $17 \%, 19$ to $25-26 \%$ and under $18-6 \%$. Most had higher education (59\%), secondary education $31 \%$ and 4\% vocational education [Leoniewska 2011].

All respondents sorted out waste, $44 \%$ claimed that they have been segregating for four years already $(50 \%$ of those before mentioned said that they are segregating rubbish for more than six years). $17 \%$ of the respondents has been using containers for particular waste fractions for a year. According to article 3 paragraph 2 of amended Act on maintaining cleanliness and order in municipalities [Journal of laws 2011], communes are also responsible for performing informational and educational activities concerning proper behaviour with the municipal solid waste management (especially selective municipal solid waste management). Inhabitants declared (in 2011) that informational and educational campaigns broadcasted in the mass media (on television/ in newspapers) influenced the most, their choice to start sorting out waste.

Most residents performed individual waste collection: paper and cardboard (90\%), plastic (72\%) and glass (55\%) (Figure 2.) [Leoniewska 2011]. Among the fractions above mentioned waste paper was collected in almost every household. According to agreement with a waste treatment plant, inhabitants could use paper and cardboard container free of charge. Most recycled materials were gathered in drop-off points located in the administrative housing estate area Swojczyce-Strachocin-Wojnów. 55\% of respondents stated that at the points there were also containers for paper and cardboard (among those for clear and coloured glass and plastic). This was not true.

In case of hazardous waste (batteries and accumulators, WEEE) only $40 \%$ of respondents de- 


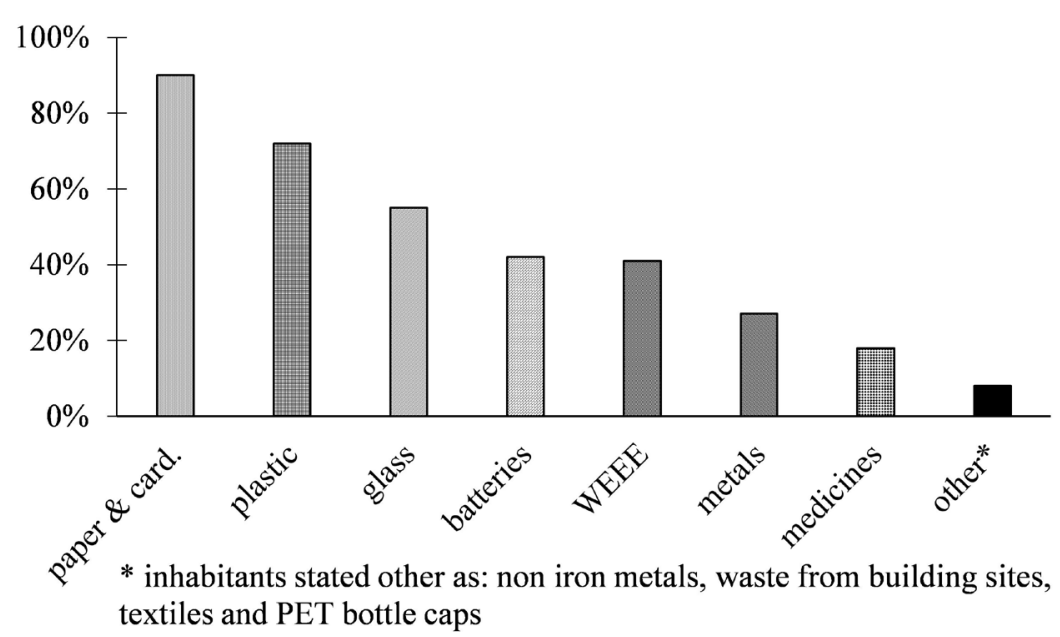

Figure 2. Waste fractions selectively collected by inhabitants of Wojnów housing estate (per cent of respondents) [Leoniewska 2011]

clared. Sorting out WEEE took place mostly in private mechanical and biological treatment plants where used electronic and electric devices could be disposed of for free. Only $18 \%$ respondents did not throw unused and expired medicines into mixed waste container. Having in mind, that at that time there was no special container prepared.

The worst part of the existing in 2011 selective waste collection system was too few drop-off points including containers for particular waste fractions (only $18 \%$ respondents claimed that there were enough containers). Another issue was the localisation of the points, up to $59 \%$ respondents stated that the containers were badly located. This problem was directly connected with the low number of points. Accessible containers will definitely encourage residents to segregate waste $(68 \%$ of respondents started sorting out at least one waste fraction just only when the right containers appeared). Door to door system is more expensive (management service) but enables gaining more recycled waste containing low contamination.
The respondents paid attention to the frequency of waste collection. Almost $40 \%$ claimed that containers are not only located to far but also they are overfilled (Figure 3) [Leoniewska 2011]. It wasn't a problem only of the analysed area. At this time inhabitants of some other cities also claimed that the containers are overfilled and they can't dispose waste [Banaszkiewicz et al. 2013, Pasiecznik et al. 2013a, 2013b].

It was alarming that some inhabitants were convinced that waste treatment plants mix all waste fractions after collecting (17\% of respondents, Figure 3). The above mentioned belief levered up the sense of selective waste collection and indicated necessity of introducing informational and educational campaigns concerning the waste collection and management.

Some questions in the survey were supposed to elicit inhabitants' knowledge about selective waste selection management (multi-container municipal solid waste collection system). Only $31 \%$ of the respondents indicated correctly the

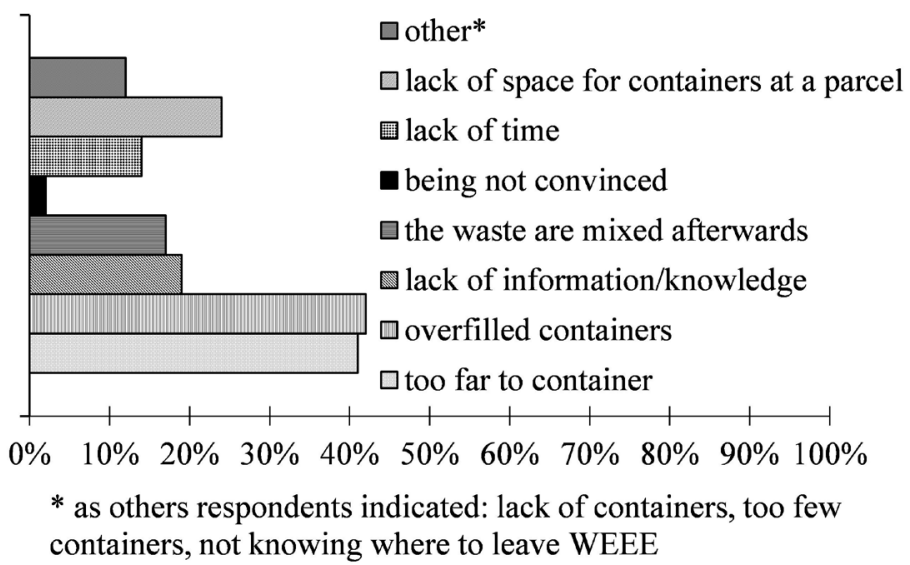

Figure 3. Factors discouraging inhabitants from sorting waste [Leoniewska 2011] 
colour of the container designed for: paper (blue), plastic (yellow), clear glass (white) and coloured glass (green).

In the following part of the survey the residents were asked to which container they should put different kinds of waste. The most frequent mistake concerned paper and glass containers. Most respondents thought that they can throw composite materials (tetra packs) like: juice cartons and greasy or dirty paper to paper container, respectively 30 and $28 \%$. According to legislation, communes decide about the selective waste management; the number of containers (multi and double containers etc.) and kinds of gathered fractions. In the analysed period, in many communes the composite materials were gathered together with paper. Additional waste division in the multi-container system introduced in some communes could have influenced the accuracy in the waste collection. Frequently, it was the issue in cities with lots of temporary inhabitants (e.g.. students).

Moreover, many residents thought they could put clear glass and other materials like mirrors, light bulbs or window glass into the containers prepared for the coloured glass (Figure 4) [Leoniewska 2011]. They were also wrong about the clear glass containers. Most respondents (76\%) thought they could put window glass or bulbs $(21 \%)$ into the clear glass container.

The audit, conducted in 2011 in Wrocław, controlling the selective waste containers: plastic, glass and paper shown that most containers (which belonged to different companies) did not have any information about things inhabitants should/should not throw into the containers [Bachorz et al. 2011]. The lack of knowledge con- cerning the usage of the particular containers and no description on the containers results in contamination of the gathered material fractions and even residents' resigning from sorting out waste.

\section{CONCLUSION}

The main objective of all selective collection managements is to gain as much recycled materials as possible. It can be only done with the help of the public highly involved in the environmental issues. The unlimited access to selective waste containers is only one of the factors that will encourage people to sort out waste. Even more important (maybe the most important) is public's environmental consciousness and the belief that selective waste collection really influences the environment. The waste collection system should be intuitive and consulted with the inhabitants, not waste treatment plants, especially while introducing.

The research has shown that the waste management which was obligatory at Wojnów housing estate in 2011 did not work properly and needed remodeling. Although, the inhabitants were willing to segregate particular material fractions they had difficulties in accessing the containers. The survey has also shown that the waste treatment plants did not pay enough attention to the informational campaign. Most respondents were not aware of the destination of the particular containers which resulted in more contaminated selectively collected material fractions.

The residents of Wojnów had no idea how the particular waste fractions are recycled. There were many respondents who thought that all

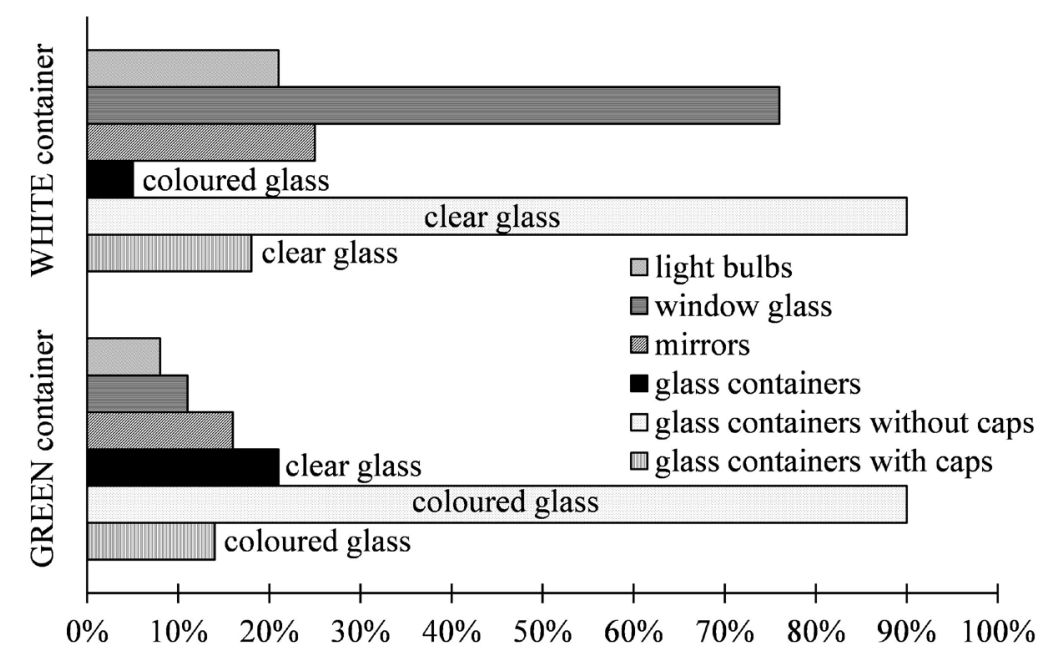

Figure 4. Clear/coloured glass container destination (according to respondents) [Leoniewska 2011] 
waste is mixed during collection and disposed in landfills. The opinion analysis has shown that forcing people to sort out waste by increasing the prices for collecting waste without raising their awareness about thermal or mechanical and biological waste treatment might be insufficient. The above mentioned solution will increase the amount of sorted waste but for sure the fractions will be highly contaminated. Taking into consideration the costs of multi-container system, including door to door service, collecting and sorting particular waste streams, it would be wise to consider collecting all waste fractions, destined for recycling, to one container.

\section{REFERENCES}

1. Bachorz M. et al., Report cocnerning the audit of the selective waste containers destined for plastic, glass and paper in Wrocław. Wrocław 2011 [in Polish].

2. Banaszkiewicz K., Pasiecznik I., Racz P. 2013. The evaluation of selective municipal waste collection. In: Traczewska T. (Ed.) Interdysciplinary issues in engineering and environment protection. Vol. 3, Oficyna Wydawnicza Politechniki Wrocławskiej, Wrocław, 23-33 [in Polish].

3. Central Statistical Office. Municipal infrastructure in 2007, Warsaw 2008 [in Polish].

4. Central Statistical Office. Municipal infrastructure in 2008, Warsaw 2009 [in Polish].

5. Central Statistical Office. Municipal infrastructure in 2009, Warsaw 2010 [in Polish].

6. Central Statistical Office. Municipal infrastructure in 2010, Warsaw 2011 [in Polish].

7. Central Statistical Office. Environmental Protection 2011, Warsaw 2011 [in Polish].

8. Central Statistical Office. Municipal infrastructure in 2011, Warsaw 2012 [in Polish].

9. County Waste Management Plan for Lower Silesia 2012, Wrocław 2012 [in Polish].

10. Central Statistical Office. Municipal infrastructure in 2012, Warsaw 2013 [in Polish].

11. Jędrczak A., Szpadt R. 2006. Research methodology on sieve, morphological and chemical composition of municipal solid waste. Paper written for the Ministry of Environment, Zielona Góra, Ka- mieniec Wrocławski [in Polish].

12. Journal of laws. Act on amending the Act on maintaining cleanliness and order in municipalities from 1 July 2011 Dz.U. 2011 nr 152 poz. 897, 2011 [in Polish].

13. Journal of laws. Act on Waste from 14th December, Dz.U. 2013 poz. 21, 2013 [in Polish].

14. Kaca E., Kaca G. 2012. Mass indices of the wastes in Poland in light of the statistical data, Problems of Agricultural Engineering, 3(77), 123-134 [in Polish].

15. Kwiatkowski M., Faszczowy K. 2004. The selected aspects of the municipal waste management in Poland. In: Bytnar K., Jodłowski G.S. (Eds.), Oils and Energy of XXI century. Uczelniane Wydawnictwa Naukowo-Dydaktyczne AGH, Kraków, 329-332 [in Polish].

16. Leoniewska J. 2011. Evaluation of the effectiveness and social acceptability of selective and nonselective collection of municipal waste from outskirts of the selected town. Diploma Thesis, Wrocław University of Technology [in Polish].

17. Pasiecznik I., Banaszkiewicz K., Purwin M. 2013. Survey research concerning the opinion about selective municipal waste collection. In: Manczarski P. (Ed.) Waste management. Polskie Zrzeszenie Inżynierów i Techników Sanitarnych. Oddział Wielkopolski, Poznan, 573-584 [in Polish].

18. Pasiecznik I., Banaszkiewicz K., Szczepaniak J. 2013. Inhabitants opinions about selective municipal waste collection. In: Traczewska T. (Ed.) Interdiscplinary issues in engineering and environmental protection. Vol. 3, Oficyna Wydawnicza Politechniki Wrocławskiej, Wrocław, 491-500, [in Polish].

19. Website 1. The Free Encyclopedia, https:// pl.wikipedia.org/wiki/Wojnów (3.02.2014) [in Polish].

20. Website 2. Settlements Information Service Swojczyce-Strachocin-Wojnów, www.swojczyce. pl (3.02.2014) [in Polish].

21. Website d3. ALBA, http://www.wrocław.alba.com. pl/firma/aktualnosci,news93.html, (27.11.11) [in Polish].

22. Website 4, Municipal Road and City Maintenance Administration, Used batteries, www.zdium. wroc.pl/attachment/file/135/zuzyte_baterie.pdf (28.11.2011) [in Polish]. 